\title{
BESINNING OOR DIE VIERING VAN DIE HEILIGE NAGMAAL
}

\author{
J.H. van Wyk \\ Departement Dogmatologie \\ HTS / PU vir CHO \\ HAMMANSKRAAL/POTCHEFSTROOM
}

\begin{abstract}
A wide varicty of of fonns in which Christians partake of Holy Communion still exists today. Calvin prefered the communio ambulatoria (communicants walking to and from the table), while Zwingli practised the communio sedentaria (communicants stayed seated in the pews). A variant of the latter practice is found in the Dutch Refomed Clunch in South Africa. Since the sideenth century a forn of lable-community has developed in the Reformed Churches in the Netherlands and thence spread worldwide amongst Reformed Churches. This is still the practice todey in the Reformed Churches in South Africa. This wide variety of forms raises the question whether Scripture demands only one form of panicipation / communion. The author investigates the question and concludes by indicating some ways of finding an answer.
\end{abstract}

\section{INI EIIDING;}

Wanneer daar oor die wyse van viering van die Nagmaal besin word, en dus ook oor die vraag na die beker of kelkic, kan dit nie op verantwoorde wyse gedoen word sonder 'n duidelike eksegetiese onderbou nie (vgl. Ridderbos, 1950:337-372; 1966:463-478; Lekkerkerker, 1961:7-49; Jones et al, 1983:148-168; Koers, 1990,55(1) ). Die vraag na die Skrifheroep speel ook hier 'n baie belangrike rol. Voorts moet ook deeglik besef word dat liturgiek nooit van dogmatiek (in besonder ekklesiologie) losgemaak kan word nie, maar op 'n besondere wyse daardeur beïnloed word, soos Noordmans (1986:49-51,97) tereg opgemerk het (vgl. ook Berkouwer,1954). "Liturgie is een soort populaire dogmatiek" (Noordmans, 1986:51).

Dit is egter nie ons bedoeling om by hierdie geleentheid die eksegetiese en dogmatiese aspekte breed uit te spel nie, hoewel dit natuurlik telkens in die bespreking na vore sal kom. Daar kan immers nie sinvol oor die liturgie, in ons geval die wyse van die Nagmaalsviering, gehandel word sonder om 'n ope oog te hê vir die eksegetiese en dogmatiese wortels daarvan nie.

Ons vestig die aandag eerstens op die verskynsel van pluriformiteit ten opsigte van die Nagmaalsviering (vgl. Dankbaar, 1987; Vrijlandt, 1987:227-228; Runia, 1990); daarna word die verskillende metodes van viering beredeneer, om uiteindelik met 'n samevaltende konklusie af te sluit. 


\section{PL.URIFORMITETI}

\subsection{Dic Christologiese viering}

In hierdie verband spreek dit eintlik vanself dat in die eerste plek verwys sal word na die instelling en viering van die Nagmaal deur Christus self soos dit deur die evangeliste (Matt. 26:26-29; Mark. 14:22-25; Luk.22:14-20; vgl. Joh. 6:51-56) en Paulus ( 1 Kor. 10:16-17) aan ons oorgelewer is. Uit hierdie gegewens blyk onder meer die volgende (vgl. Bouwman,1970:421). Afgesien van die elemente van gebed, woord en lied

- het die Nagmaalsviering die vorm van 'n maaltyd aangeneem, waardeur die motief van gemeenskap onderstreep is;

- het dit aan tafel plaasgevind en wel so dat almal teenoor mekaar plek ingeneem het en mekaar kon sien;

* is daar volgens Oosterse gewoonte by die tafel aangelê en nie aangesit nie;

* is daar (ongesuurde) brood gebruik

- wat ten aanskoue van die dissipels gebreek is;

- is daar (gegiste) nyn gebruik en

- het almal uit een beker gedrink.

Hiermee is uiteraard nie beweer dat al hierdie elemente vanselfsprekend ewe belangrik is vir 'n korrekte viering van die Nagmaal nie. Die aksent val, NuweTestamenties gesien, duidelik op die brood en wyn omdat albei simbooldraers is van die offer van Christus vir ons sonde en ook dien as 'n spys en drank van die ewige lewe, terwyl die motief van gemeenskap met Christus en met mekaar ook benadruk word (1 Kor. 10:17).

Wat die Nagmaalsteologie betref, moet duidelik onderskei word tussen

* die betekende Saak (Christus),

* die tekens (brood en wyn) en

- die wyse waarop die tekens gebruik word.

Wanneer hierdie drie aspekte nie behoorlik onderskei word nie, wanneer die tekens ten koste van die saak beklemtoon word, die genademiddel ten koste van die genade (vgl. Noordmans 1986:68), dan is ons siening van die betekenis en funksie van die Nagmaal foutief. Die Nagmaalsformulier waarsku tewens dat ons "nie met ons harte aan die sigbare tekens van brood en wyn verkleef sal bly nie ...". In die tekens gaan dit om die saak, om Christus. Kerkregkundiges en liturgiekoloë is selfs van mening dat in tye van krisis iets anders as brood en wyn geoorloof is (Bouwman, 1970:419-420, met verwysing na Calvyn; Van Dellen \& Monsma, 1954:262-263; Rayburn, 1980:266-267). 


\subsection{Die Calvynse viering}

'n Tweede vorm van Nagmaalsviering waarop ons die aandag vestig, is die metode wat deur Calvyn gebruik is, naamlik dat die kommunikante na die tafel gekom het en al wandelende die Nagmaal gevier het terwyl hulle die brood en wyn uit die hand van die predikant(-e) (en later diakens) ontvang het (die sg. communio ambulatoria) (Dankbaar, 1987:47,50,51; Brienen, 1987:218; Balke, 1980:223).

Baie bekend is Calvyn se duidelike onderskeiding tussen middelmatige en fundamentele sake - 'n onderskeiding wat hy, opvallend genoeg nie net ten opsigte van die liturgie hanteer nie (vgl. in verband met die Nagmaalsviering, Institusie, 4,17:43, en in verband met die handoplegging by boetedoening, Institusie, 4,19:14), maar ook ten opsigte van die etick (in verband met die Christelike vryheid (wyn drink), Institusie, $3,19: 7 / 13$; in verband met die gewete, $4,10: 4$; in verband met vas, 4,12:19) en selfs die dogmatick $(4,1: 12)$. So is dit vir Calvyn heeltemal 'n middelmatige saak of daar gesuurde of ongesuurde brood, wit of rooi wyn gebruik word. Wat hy egter onvoldoende ag, is om die Nagmaal slegs onder een teken te vier (4,17:47). Die Roomse praktyk van 'n eucharisticviering slegs met brood, soos sedert die negende eeu gebruiklik geword het (Rayburn, 1980:266), en dan slegs een maal per jaar, was vir Calvyn volkome onaanvalirbaar. Opvallend is dat Calvyn sy liturgiese aanwysings plaas binne die breë raamwerk van wat ons 'n teologie van die Nagmaal sou kon noem. Buite hierdie konteks verloor die middelmatige sake hul relatiewe betekenis en kan hulle op so 'n wyse verabsoluteer word dat die fundamentele sake nie meer sentraal bly nie. Op hierdie wyse vind daar dan 'n fatale plaasvervanging plaas, word die aksent van hoofsake na bysake verlê en word die ware betekenis van die Nagmaal en Nagmaalsviering skeefgetrek.

Dit is verder opvallend dat Calvyn die sakramentsleer, soos ook die kerkleer, in boek 4 van sy Institusie onder die tema "uiterlike hulpmiddels" behandel. Die hoofsaak van sy dogmatiek bestaan uit 'n behandeling van die Patrologie (die leer oor die Vader, boek 1), die Christologie (die leer oor Christus, boek 2) en die Pneumatologie (die leer oor die Heilige Gees, boek 3). I aarby word in die Institusie self niks oor die wyse van die Nagmaalsviering gerep nie. Die wyse van Nagmaalsviering was vir Calvyn 'n middelmatige saak en daarom verbaas dit ook nie dat in die tyd van die Reformasie 'n wye verskeidenheid van Nagmaalsvierings voorgekom het. So vind ons by Luther (in aansluiting by die Middeleeuse praktyk) 'n knielende houding, by Zwingli 'n in die bank sittende houding en by Calvyn 'n wandelende houding. In noue aansluiting hierby formuleer die bekende Dordtse Kerkorde, tans nog in gebruik by die Gereformeerde Kerke in Suid-Afrika (GKSA), dat "elke kerk die Nagmaal moet hou op die wyse wat na sy oordeel tot die meeste stigting dien" (art. 62), met die byvoeging dat die uitwendige seremonies, soos in die Skrif voorgeskryf, nie verander mag word nie, dat alle bygeloof vermy moet word (klaarblyklik 'n verwysing na die aanbidding van die elemente, gesteun deur 'n knielende houding) en dat die formulier gelees moet word. 
Die Nagmaalsviering wat Olevianus en Ursinus, opstellers van die Heidelbergse Kategismus, in die Palts geken het, was die wandelende kommunie (Dankbaar, 1987:75-77).

\subsection{Die Zwingliaanse viering}

'n Derde wyse van kommunikeer is waar die lidmate in die banke bly sit terwyl die brood en wyn vanaf die tafel (deur diakens) bedien word, soos by Zwingli die geval was (communio sedentaria) (Dankbaar, 1987:32-33). Vandag word hierdie wyse van viering aangevul met 'n tafelbediening sodat alle lidmate gelyktydig Nagmaal vier, sommige aan tafel en die res in die banke. Laasgenoemde standpunt probeer dan 'n midóeweg vind tussen ' $n$ viering aan tafel (eintlik verskillende tafels) enersyds en 'n viering in die banke andersyds en is in ons eeu reeds eerder deur onder andere Van Dellen en Monsma (1954:260) bepleit.

Nou moet daarop gewys word dat die gebruik om aan tafel te sit, afgesien van die periode tydens die heel vroegste kerkgeskiedenis, vir eeue totaal verdwyn het. Dit is trouens ' $n$ tipiese Nederlandse gewoonte en vandaar het dit oor die wêreld versprei waar Nederlandse Gereformeerde Kerke gevestig is (Kuyper, 1911:458; Balke, 1980: 223). Rondom die middel van die sestiende eeu het A Lasco en Micron die sittende tafelviering in die Nederlandse vlugtelinggemeente in London ingevoer toe dié gebruik elders nog onbekend was (Dankbaar, 1987:60-65; Trimp,1983:132). Die simboliek wat hieruit na vore sou kom, was dat dit 'n teken sou wees van rus in God, van toekomstige heerlikheid en van die eenheid en vrede van die gemeente (Vrijlandt, 1987:96). Daar was ook meer as een tafel, met eers die mans en daarna die vrouens as kommunikante (Vrijlandt, 1987:96). In Nederland het die tafelviering in Emden ontstaan onder Aportanus en in Norden onder Rese (Dankbaar, 1987:55; Balke, 1980: 223). Die tafelviering soos dit vandag bekend is, dateer dus vanaf die sestiende eeu en is nie iets wat alle eeue deur voorgekom het nie.

Van Dellen en Monsma probeer, soos gesê, die tafel- en bankviering kombineer. Wel voer hulle (1954:261) aan dat 'n gesamentlike beker uitdrukking van Christelike eenheid is, maar, sê hulle (1954:261)

We believe that it should be granted that the introduction of individual cups at the Lord's Table does not concern the essence of the Sacrament. We do lose a bit of symbolism but we lose nothing regarding the essence of the Lord's Table.

Teenoor wat verloor word, moet opgeweeg word wat gewen word, naamlik beter higiëne (1954:261). Hierdie motivering is natuurlik eerder prakties as teologies gefundeer en as sodanig nie deurslaggewend nie; so ook is hulle voorstel (1954:260) dat kommunikante in die voorste kerkbanke plaasneem ook nie baie sinvol nie aangesien dit kinders in 'n groot mate "ekskommunikeer". 
Maar nie net in die Christian Reformed Churches van Amerika kom hierdie visie voor nie - ook in Suid-Afrika word dit aangetref. Dit het by ons trouens 'n hele aanloop gehad. Tydens die Nasionale Sinode van Potchefstroom 1988 dien die kerkraad van die Gereformeerde Kerk Linden 'n beswaarskrif in teen die besluite van Sinode Burgersdorp 1930 waartydens 'n uitspraak oor (teen!) die gebruik van kelkies gemaak is (Handelinge GKSA 1988:556-561). In die beswaarskrif word aangevoer dat Sinode 1930 naas die brood en wyn 'n derde teken, naamlik die tafel, in stryd met die Skrif en die Gereformeerde tradisie, toegevoeg het. Sinode 1988 aanvaar 'n kommissierapport waarin die besware afgewys word en waarin eksplisiet vermeld word dat "Sinode 1930 inderdaad 'n prinsipiële uitspraak oor die Nagmaalstafel as 'n wesentlike element van die Nagmaalsviering gemaak het" (Handelinge GKSA, 1988:562-565). Hiermee is dus uitspraak gedoen ten gunste van drié tekens by die Nagmaal, te wete brood, wyn én tafel.

Teen hierdie besluit van die Nasionale Sinode Potchefstroom 1988 is daar by die Algemene Sinode Potchefstroom 1988 twee appèlskrifte ingedien. Die Algemene Sinode gee die appellante gelyk en bevind dat die Nasionale Sinode van Potchefstroom sy oordeelsbevoegdheid oorskry het deur sonder Skrifbewyse die tafel as derde wesentlike element van die Nagmaalsviering in te voer (Handelinge, Algemene Sinode,1988:120-128). Duarmee is natuurlik nie uitspraak gedoen ten gunste van die afskaffing van die tafelgemeenskap nie.

Sover my kennis strek, word die metode van gesamentlike en gelyktydige Nagmaalsviering aan tafel en in die banke tans deur die Gereformeerde kerke Linden en Kaapstad toegepas (en deur Potchefstroom-Noord oorweeg). Dit kom konkreet daarop neer dat lidmate wat verkies om by die tafel aan te sit, daarvoor geleentheid gegee word, terwyl die ouderlinge en/of diakens die bediening vanaf die tafel na die banke uitbrei. Vanselfsprekend vra dit goeie organisasie en baie bekers, maar dit onderstreep die gedagte van gemeenskap en duur ook korter. Daarby kom hierdie vorm van viering, soms ook sonder tafelbediening, veelvuldig in die sogenaamde jonger Gereformeerde kerke voor.

\section{$2.4 \quad$ Die Alberlynse viering}

'n Vierde wyse van Nagmaalsviering, waarin die gesamentlike karakter beklemtoon word, is die sittende viering in die banke met klein bekertjies (meesal ook kelkies genoem), soms aangevul met 'n tafelbediening en rondgaande bekers. Hierdie metode staan ook as Skotse viering bekend (Vrijlandt,1987:228). In SuidAfrika kom dit vandag wydverspreid in die Nederduitse Gereformeerde Kerk (NGK) voor. Dit is sover bekend die eerste keer op 8 Januarie 1888 in die Ned. Geref. Kerk Riversdal onder leiding van ds. J.R. Albertyn vanweë praktiese oorwegings ingestel (Du Toit 1962:49; De Bruyn,1964:21). 
Jac Müller (1957:66) wys in verband met die gebruik van kelkies daarop dat die tekens by die Nagmaal net brood en wyn is en dat dit "nie veel saak maak op welke wyse ons die wyn drink nie". Die besware teen die beker is prakties van aard: dis onkies en hinderlik en dis onhigiënies. Juhian Müller (1990:89) weer wyt die ontstaan van kelkies nie aan higiène nie maar aan die groot gemeentes. Hy ag kelkics aanvaarbaar maar meen tog dat een brood en een beker en een tafel meer ideaal sou wees (1990:89,90).

De Klerk (1982:98) vestig die aandag op sowel die voor- as nadele van die tafelgemeenskap: voordelig is dat dit die maaltydkarakter onderstreep, opsig vergemakiik en dat die toetrede tot die tafel as geloofsdaad aan die lig tree; nadelig is dat dit lank neem en onrustigheid skep. Die voordele van die bankkommunie is dat dit korter duur, rustigheid skep en die eenheid van die gemeente beter tot uitdrukking bring. Du Toit (1962:53) verkies weer dat bekers gebruik word en dat kommunikante apart moet sit om toesig te vergemaklik.

Die bloot praktiese fundering van die bank- en kelkkommunie het heelwat kritiek opgeroep (De Bruyn,1964:18-20; Kruger,1956:116-117). Die hoofbesware wat aangevoer word, is dat dit die gemeenskaps- en maaltydkarakter van die Naginaaisviering aantas, dat dit van licfdeloosheid en selfs ongeloof getuig en dat dit die toesighouding benadeel. Volgens Kruger (1956:116) is "kelkies dus 'n openbaring van eiegeregtige trotsheid en verwaandheid. Die egte liefde ontbreek vir mekaar". Ons kom later weer hierop terug.

In Nederland kom die gebruik van bekertjies onder andere in die Nederlandse Gereformeerde Kerken voor en opvallend is dat die GKSA nooit hierteen beswaar gemaak het en dit nooit as argument gebruik het toe die gemeenskapsbande (enger korrespondensie) met die GKN in 1976 opgesê is nie. Nauta (1971:276), in sy bespreking van artikel 76 van die kerkorde van die Gereformeerde Kerken in Nederland (GKN), oordeel dat daar by die Nagmaalsviering met "praktiese oorwegings", soos die aantal kommunikante en gesondheidsaspekte, rekening gehou moet word en dat veel daarvoor pleit dat klein bekertjies uitgereik word.

\subsection{Die Aportanusiaanse viering}

In die vyfde plek kan gewys word op (groeps-)viering aan (verskillende) tafel(-s) met verskeie bekers, soos tans in gebruik is by die Gereformeerde Kerke in SuidAfrika - asook in die Nederduitsch Hervormde Kerk van Afrika (Beukes,s.j.:27; Koekemoer, 1978:11). Ons het reeds daarop gewys dat hierdie gebruik na die sestiende eeu (Aportanus) teruggevoer kan word en as 'n spesifiek Nederlandse viering getipeer kan word. Ook Kuyper (1911:467-470) was 'n groot voorstaander 
van hierdie wyse, veral van die maaltyd-en tafelgemeenskap, maar sonder om ander vierings te diskrediteer. Hy rig hom wel skerp teen ' $n$ individualiseringstendens (1911:470), maar stel ook dat 'n mens nie kan sê nie "dat het aanzitten aan den disch voor de viering van het Heilig Avondmaal volstrekt noodzakelijk is; maar wel beveelt het zich als de meest gewijde vorm van bediening van Avondmaal aan " (1911:467). En verder

Iets wat hicr niet gezegd wordt, alsol onder geen omstandigheid het Sacrament anders dan aanzittende aan een tafel zou kunnen of mogen genoten worden. Dan zoudt ge het geestelijk karakter van het Sacrament te nakomen. Maar wel volgt er uit, dat de onder ons gangbare gewoonte om het Heilig Avondmaal rittende om den disch te genieten, het best beantwoordt aan de ordinantic van de instelling (1911:40(9).

Kuyper (1911:471-472) huiwer nie om die moeilikhede rondom tafelviering uit te spel en daarvoor 'n oplossing (nommerstelsel) aan te bied nie. So verwys hy onder andere na die lang tydsduur en dat lidmate rug aan rug aan die tafel aansit waardeur die gemeenskap uiteraard benadeel word.

Die standpunt van Kuyper word deur Bouwman (1970:411-412) voortgesit. Ook hy beklemtoon die maaltydkarakter en oordeel dat dit die mees gewyde vorm van Nagmaalsvicring is, maar voeg by dat aansit aan die tafel nie "volstrekt noodig" is nie (1970:411/413). Die nadeel van die bankbediening is dat die maaltydkarakter verlore gaan, mar die voordeel is weer dat dit die eenheid van die gemeenskap van die heiliges onderstreep (1970:413). Opvallend is dat ons by Suid-Afrikaanse kerkregkundiges presies die omgekeerde argument vind: die bankbediening verbreek die eenheid en die tafelbediening onderstreep dit (vgl. Kruger, 1966:380). Bouwman (1970:413-414) sluit nie sy ö̈ vir die probleme rondom die (veelvuldige!) tafelbediening nie, soos byvoorbeeld dat dit die eenheid aantas, dat dit gedrang veroorsaak en dat dit 'n groot liturgiese ruimte verg. Ook hier weer val dit op dat, met die uitsondering van J.D. du Toit, Suid-Afrikaanse kerkregkundiges nié die nadele van 'n veelvuldige lafelbedinging oorweeg nie. Veroorsaak 'n grocpsviering aan baie tafels nie dalk meer "onenigheid" nie en bevat dit nie dalk minder gemeenskaplikheid as wanneer almal die Nagmaal gelyktydig in die banke vier nie?

Op hierdie stadium moet ons egter gaan kyk na die sinodale besluite van die GKSA in 1927 en 1930, besluite wat vir baie jare as rigtinggewend vir die wyse van Nagmaalsviering gegeld het.

Sinode 1927 (Handelinge 1927:14) kry te doen met 'n beskrywingspunt wat handel oor die vraag "hoe gehandel moet word met lidmate wat om gesondheidredes beswaar maak teen die gebruik van die gesamentlike awendsmaalbeker". Die 
Sinode besluit (Handelinge 1927:52,169) "dat die kerkrade hulle sal bepaal by 'n gemeenskaplike beker soos dit tot hiertoe by ons gebruiklik was, omdat dit volgens die instelling van Christus is (Lukas 27:17, Mark. 4:23.). Spesiale gevalle van gevaar vir besmetting berus by die kerkraad". Verder besluit die Sinode om 'n kommissie te benoem "om op die volgende Sinode 'n beredeneerde advies uit te bring wat die gronde aangee waarom die Geref Kerk die gemeenskaplike beker handhaaf by die Nagmaalstafel, en waarom ons nieteenstaande die gesondheidsbesware geen aparte kelkies wil gebruik nie". Wat in hierdie besluit opval, is dat die Sinode die saak sonder ' $n$ indringende studierapport en slegs met verwysing na enkele Skrifdele afhandel en daarna opdrag gee dat die teologiese fundering verskaf moet word. Dit skyn asof die Sinode, sonder om na die kerkhistoriese verloop van die Nagmaalsviering deur die eeue te gaan kyk, van die voorveronderstelling uitgegaan het dat slégs die tafel-en bekerbediening die enigste verantwoorde metode is. Die kommissie wat die saak ondersoek het, gaan dan ook van die vertrekpunt uit dat Sinode 1927 hom prinsipieel teen die gebruik van afsonderlike kelkies uitgespreek het "en aan die kommissie slegs opdrag gegee het om die redene, wat tot hierdie uitspraak gelei het, te formuleer " (Handelinge, 1930:48).

Die kommissierapport wat op Sinode 1930 dien, word in sy geheel aanvaar (Handelinge, 1930:48-50). Daarin kom die volgende argumente na vore.

- Eerstens is die gebruik van aparte kelkies in stryd met die leringe van die evangeliste en Paulus (Matt. 26:27,28; Mark. 14:23; Luk. 22:20; 1 Kor. 11:25-29). Hieruit blyk duidelik dat die Nagmaal as broedermaaltyd bedoel is met een gemeenskaplike beker aan 'n gemeenskaplike tafel.

- Tweedens is die kelkies in stryd met die simboliek van die Nagmaal as 'n geestelike gemeenskapsmaaltyd. "Die invoering van aparte kelkies maak die awendmaal ' $n$ individualistiese saak." "Eers as die gelowiges saam aan een tafel aansit, as hulle eet van dieselfde brood, en drink van dieselfde drinkbeker, kom daarin simbolies die éénheid van die liggaam van die Here uit." Veelseggend word in hierdie verband opgemerk - 'n opmerking waarvan die betekenis nie altyd konsekwent gehandhaaf is nie - dat "daarmee nie beweer word nie dat by so' $n$ individualistiese gebruik van die Nagmaal die sakrament sy werking nie kan doen nie".

- Derdens word aangevoer dat ' $n$ individualistiese viering met kelkies ' $n$ gees van liefdeloosheid en individualisme in die hand werk en die band van liefde en samehorigheid verswak. Dit kom neer op veragting van medegelowiges. 
* Vierdens kom die drang na aparte kelkies soms voort uit 'n gees van ongeloof. Die gevaar van besmetting vanweë die gebruik van 'n gemeenskaplike beker is wetenskaplik nog nie bewys nie.

Later tydens dieselfde Sinode kom die saak weer eens ter sprake en wel in vraagvorm (oorspronklik) van die kerkraad van De Aar: Mag lidmate in "ons kerkverband" opgeneem word indien hulle aan 'n kerk behoort wat kelkies gebruik waarteen hulle dan besware het (Handelinge, 1930:15\%-159)? Hierdie saak word nou deur die kommissie vir dogmatiese en kerkregtelike sake hanteer en dit val op dat, hoewel daar na die reeds genome besluit verwys word, die toon van argumentering (en dus die besluit) aansienlik skerper is. Anders as in die vorige besluit, waar toegegee is dat by die gebruik van kelkies die sakrament "sy werking nog kan doen", word die saak van kelkies nou in verband gebring met 'n poging van Satan om die merktekens van die ware kerk te vervals. Dit word 'n hele proses van vervalsing en 'n glybaan na verwêreldliking: eers word die tafelbediening met bankbediening vervang, daarna die beker met kelkies, en uiteindelik die wyn met druiwesap. Hierdie "strekking" van die beweging vir aparte kelkies is 'n "hoogernstige verskynsel". Op die vraag of lidmate van ander kerke dus in "ons kerkverband" opgeneem mag word, moet $j a$ en hee geantwoord word. Ja, as sodanige lidmate die Gereformeerde belydenisskrifte van harte toestem "en die beweging vir individuele kelkies deursien in sy strekking as kerkvervalsing". Nee, indien lidmate slegs besware teen kelkies het omdat dit van die tradisie afwyk.

Reeds op hierdie stadium kan twee vrae in verband met die erns en reikwydte van hierdie besluite gestel word.

" Eerstens, indien die groot woord "kerkvervalsing" dan hier geval het, waarom het die salak van kelkies nog nooit in die tussenkerklike gesprek tussen die GKSA en die NGK gefigureer nie? Moet ons aanvaar dat die opmerking van J.C. Kruger (1980:165) korrek is dat "met dankbaarheid gekonstateer kan word dat die wyse van Nagmaalsviering skynbaar nie 'n strydpunt is nie"?

* Tweedens, as die bankbediening met kelkies met kerkvervalsing in verband gebring kan word, waarom het die GKSA nooit enige beswaar gehad teen buitelandse Gereformeerde kerke met wie ons in kerklike gemeenskap (enger korrespondensie) staan terwyl daar by hulle wel so 'n Nagmaalspraktyk aangetref word? Hierdie aspek het byvoorbeeld nooit ter sprake gekom tydens die breuk van die GKSA en die GKN in 1976 nie. Die konklusie lyk onvermydelik dat artikel 85 KO ook op die bank- en kelkieviering van toepassing is, naamlik dat in midde/matige dinge moet buitelandse kerke by wie ander gebruike as by ons in swang is, nie veroordeel word nie." 
Die GKSA het vir baie lank 'n skeptiese houding teenoor bank- en bekertjiebediening ingeneem. So kies Du Toit (Totius) $(1977: 279,282,329)$ vir 'n tafelgemeenskap, as dit kan, net een tafel. Hy bespreek die verskillende wyses van Nagmaalsviering, maar voer ' $n$ nuwe onderskeiding in deur daarop te wys dat 'n middelmatige saak nog nie 'n onverskillige saak is nie (1977:327). Openhartig stel hy (1977:281) dat "besef sal word dat die alte seer gesplitste Nagmaalviering (met baie tafels, J.H. v. W) geen ideale verskynsel is nie": dit bring 'n ongewenste skeiding tussen lidmate; die herhaling vermoei die liturg en lidmaat; die liturg raak haastig en dit veroorsaak gedrang. Sy afwysing van die kelkies (1977:294-295) is besonder gematig. (Hy skryf sy Nagmaalartikels tussen 1933 en 1935.) Hy keur kelkies af omdat die Nagmaal met 'n gemeenskaplike beker ingestel is; omdat dit die simboliek van een geestelike familie wat uit een gemeenskaplike beker drink, verswak; en omdat die aantal bekers nie 'n verskil maak nie. So verwerp hy ook die Zwingliaanse manier van bankkommunie omdat dit'n afwyking is van die instelling van die Nagmaal, die Nagmaalsimboliek laat verlore gaan en die toesig by die Nagmaal verswak (1977:330-331). Ook die uitgebreide Nagmaal (vanaf die tafel na die (voorste) banke (vgl. Van Dellen \& Monsma)), keur hy af aangesien dit die denkbeeld van'n maaltyd verswak. Nêrens bring Totius egter die bankbediening in verband met kerkvervalsing nie.

Die meeste Gereformeerde kerkregkundiges het by die sinodebesluit van 1930 dansluiting gevind. Volgens Kruger (1966:378-380) is brood en wyn die elemente van die Nagmaal, maar die tafel- en bekergemeenskap is ook nodig. Saam met Jansen (1952:276) oordeel Kruger (1966:380;1956:117) dat die gebruik van twee tot tien bekers nie dieselfde is as die gebruik van baie kelkies nie; ook word die eenheidsgedagte nie deur verskillende tafels verbreek nie. Volgens Van der Linde (1983:208) is die tafel 'n "vereiste", so ook die gemeenskaplike beker (1983:209), maar waar dit nie moontlik is nie, is drie of vier bekers aan te beveel; dit lê immers nie op een lyn met die individuele kelkies nie. Daar is nagenoeg eenstemmigheid dat die gebruik van meer bekers nie met die gebruik van baie kelkies vergelykbaar is nie (Pasch, 1930:6; Du Toit, 1977:294; Kruger, 1956:117, 1966:380; De Bruyn, 1964:21; Van der Linde, 1983:209; Spoelstra, 1989:349). Dit is egter 'n ope vraag of hierdie argument (volledig) geldig is. Ons keer later hierna terug. 


\section{OORWEGINGS}

\subsection{Die invloed van voorveronderstellings}

Ons het reeds terloops gewys op die rol wat voorveronderstellings in die kerk en teologie kan speel. Dit speel nie net 'n groot rol in ons dogmatiese en etiese besinning nie, maar ook op die gebied van die kerkreg en liturgiek. Die gevaar is wesentlik dat 'n bepaalde Nagmaalspraktyk wat met die loop van jare gegroei hel, skielik sinodaal geyk kan word en dat by nabaat teologiese begronding daarvoor gesoek kan word. Indien gekyk word na die wyse waarop die 1927-sinodebesluit geneem is en dat daarna 'n kommissie opdrag kry om 'n reeds genome besluit van 'n teologiese onderbou te voorsien, kan die vraag met reg gestel word of daar nie oorhaastig opgetree is nie en of bepaalde vertrekpunte - daar is slegs één juiste manier van Nagmaalsviering - nie te dominerend was nie. Die kommissie wat aan Sinode 1930 gerapporteer het, het ook glad nie aandag bestee aan die historiese gang van Nagmaalviering deur die eeue nie. Veral as groot woorde soos "kerkvervalsing" val, is dit uiters noodsaaklik dat indringend en breedvoerig op sake ingegaan sal word.

Gelukkig het die Algemene Sinode 1988 hier noodsaaklike korreksies aangebring.

\subsection{Die vraag na die Skrifberoep}

In talle teologiese vakke, soos byvoorbeeld in die dogmatiek en etiek, is daar in die afgelope jare 'n groot sensitiwiteit vir die korrekte Skrifberoep ('n woord wat tans veel eerder as Skrifbewys gebruik word) ontwikkel. Dit is egter 'n ope vraag of hierdie sensitiwiteit ook na die terrein van die kerkreg en liturgiek deurgedring het. Hiermee word geensins bedoel om die gesag van die Skrif te minimaliseer nie, inteendeel, maar daar word wel bedoel dat die gesag van die Skrif juis aangetas word as Skrifgegewens op 'n onnoukeurige en sorgelose wyse ter sprake gebring word (Van Wyk, 1990:55-59). So is dit uiters gevaarlik om die Bybel te gebruik (misbruik!) om 'n bepaalde voorafingenome standpunt teologies te onderskraag. Dit is onvoldoende om bloot formeel na die bekende Nagmaaltekste te verwys as genoegsame grond teen die Albertynse Nagmaalsviering.

Wanneer die Skrifgegewens rondom die Nagmaalsviering nagegaan word, blyk dit baie duidelik dat brood en wyn die elemente is waarop dit aankom. Dat die tafel en beker ook 'n bepaalde funksie verrig, moet onmiddellik toegegee word, maar darmee is nog nie gesê dat dit onder alle omstandighede 'n noodsaaklikheid is en dat daarsonder geen Nagmaal gevier sou kon word nie. Tafel en beker is nie simbooldraers wat op dieselfde vlak as brood en wyn funksioneer nie. Die gebruik 
van 'n tafel en 'n beker kan wel die simboliek versterk (of verswak), maar is nie essensiële elemente nie. As daarop gewys word dat ons so na as moontlik aan die oorspronklike (Christologiese) instelling van die Nagmaal moet kom, kan die vraag gestel word waarom vandag van ten minste sewe aspekte afgewyk word:

* Eerstens gebruik ons nie meer een tafel nie maar baie tafels;

* tweedens lê ons nie meer aan nie maar sit aan;

* derdens sit ons nie aan met gesigte almal na mekaar gekeer nie maar sommige sit rug aan rug;

* vierdens word die hele brood nie voor die oë van almal gebreek nie maar vooraf deur die koster en/of diakens;

* vyfdens gebruik ons nie ongesuurde brood nie maar gesuurde brood;

- $\quad$ sesdens gebruik ons nie een nie maar baie bekers, en

* $\quad$ in die sewende plek word die instellingswoord nie net een keer uitgespreek nie maar 'n paar keer herhaal.

Tereg word hierop geantwoord dat hierdie dinge middelmatige sake is wat, as daarin verandering kom, nie die wese van die Nagmaalsviering aantas nie. Maar, kan gevra word, waarom is die gebruik van gesuurde in plaas van ongesuurde brood aanvaarbaar (soos by Calvyn, Institusie 4,17:43; Du Toit, 1977:290 Rayburn, 1980:266) - onthou dat brood een van die spesifieke simbooldraers is - , terwyl die aanvaarding van baie bekertjies nie aanvaarbaar is nie - terwyl nie die béker nie maar die wyn simbooldraer is. (Die talle verwysings na die "beker" in 1 Kor. 11 moet waarskynlik in die konteks as stylfiguur (sinekdogee) verstaan word; vgl. egter Coetzee, 1990:43.) Baie van die argumente waarom sommige aspekte van die oorspronklike Nagmaalsviering aanvaarbaar geag word en ander nie, is nie oortuigend nie. Die Skrif word te maklik gebruik om 'n bepaalde Nagmaalspraktyk te sanksioneer.

\subsection{Die vraag na die ware en valse kerk}

Sinode 1930 het dit goedgedink om, ondanks die bepalings in artikel 62 (en 85) van die Kerkorde, die gebuik van kelkies in verband te bring met die merktekens van die valse kerk. Nou is dit natuurlik waar dat artikel 29 van die Nederlandse Geloofbelydenis die "suiwere bediening van die sakramente" as een van die 
merktekens van die ware kerk tipeer, maar dit is uit artikel 35 NGB duidelik dat slegs na twée simbooltekens verwys word, naamlik brood, as 'n sakrament van die liggaam van Christus, en wyn, as 'n sakrament van sy bloed. Artikel 35 NGB bevat geen spesifieke reëling in verband met die Nagmaalsviering nie, behalwe dat dit tydens ' $n$ erediens moet plaasvind en dat "alle bymengsels en verwerplike vindinge" wat mense by die Nagmaal bygevoeg en daarmee vermeng het, verwerp word. Hiermee word klaarblyklik verwys na die verering van die elemente, die ronddra van die heilige hostie, die kelkonthouding en die misotter (Polman, s.j.:248). Uit die lleidelbergse Kategismus (30:80) blyk dat die Reformatoriese Nagmaalsleer hom veral rig teen die Roomse transsubstansiasieleer met al die dogmatiese afwykings daaraan verbonde, onder andere dat die Nagmaal selfs onder een gestalte (slegs brood) gevier mag word en die elemente ook vereer moet word. Dit is veral hiérteen dat artikel 62 van die Kerkorde hom rig as daartoe opgeroep word om "alle bygeloof te vermy". Vandaar die gevare verbonde aan 'n knielende Nagmaalsviering. Dit is duidelik dat artikel 29 van die NGB in verband met die suiwere bediening van die sakramente veral gerig is teen 'n dogmatiese misverstaan (transsubstansiasieleer) en nie teen seremoniële nuanses wat in die Reformatoriese kerke van die sestiende eeu wydverspreid voorgekom het nie. Dogmahistories gesien, staan die vervalsing van die Nagmaalsleer in die nouste verband met die transsubstansiasieleer en nie met die uiterlike seremonies (soos die gebruik van baie bekertjies) nie. Indien die gebruik van baie bekertjies/kelkies wél as 'n poging tot kerkvervalsing gesien sou word, sou swaarwigtiger argumente as die bestalande angevoer moet word.

Die besluit van Sinode 1930 on die gebruik van bekertjies/kelkies met die vervalsing van die ware kerk te verbind, is, gesien die groot variasie van Nagmaalsvierings in die Reformatoriese kerke, 'n oorspanning van wat die reformatoriese belydenis in hierdie verhand oor die Nagmaal leer. Ons moet versigtig wees om nie in ons oorywerigheid om die seremonies suiwer te hou, toevoegsels tot die Nagmaal te maak wat die ware aard en betekenis daarvan aantas nie.

\subsection{Die onderskeid tussen fundamentele en middelmatige sake}

Daar heers wye konsensus onder gereformeerde teoloè dat daar ten opsigte van die seremonies by die Nagmaal van middelmatige sake sprake kan wees (vgl. Bouwman, 1970:415-421). Sodanige sake is byvoorbeeld of die Nagmaal staande, sittende of lopende gevier moet word (Du Toit, 1977:328; Trimp, 1983:147); of die brood gesuur of ongesuur moet wees; of dit wit of bruin brood moet wees; of dit wit of rooi wyn moet wees (Calvyn. Institusie 4,17:43; Du Toit, 1977:291); of die brood inderdaad gebreck en die wyn uitgegiet moet word (Polman, s.j.:259-260); of 
dit 'n nágmaal of dan wel 'n dágmaal behoort te wees. Hierdie sake is almal as middelmatige sake beskou sodat dit nie as geloofsverwyderende en kerkverskeurende elemente beskou kan word nie.

By elke Nagmaalsviering moet immers tussen teken en betekende saak (Christus) onderskei word. In die Nagmaal gaan dit nie in die eerste plek om die tekens nie maar om die saak, of beter gestel: in die tekens gaan dit om die saak. Ons moet nie met ons harte aan die sigbare tekens van brood en wyn verkleef bly nie, maar ons harte ophef na die hemel waar Jesus Christus is. En wat die tekens betref: daar is nie een of drie of vier tekens nie (brood, wyn, beker en tafel nie), maar volgens ons reformatoriese belydenisskrifte slegs brood en wyn. Ons het daarop gewys dat kerkregkundiges van oordeel is dat in hoogs uitsonderlike situasies selfs van ander simbooldraers of elemente gebruik gemaak sou kon word, sodat selfs die bestaande twee elemente nie as absoluut beskou moet word nie.

Die aanvaarding van brood en wyn as die eintlike simbooldraers plaas elke Nagmaalsviering in die juiste perspektief. Daarmee is natuurlik nie gesê dat die tafel- en bekergemeenskap totaal irrelevant is nie, nee, maar wel dat 'n gemeente van Christus selfs onder ' $n$ boom in die oop veld sonder 'n tafel nog sinvol die maaltyd van die Here kan vier, soos op so baie plekke in Afrika inderdaad gebeur.

\subsection{Die nadele verbonde aan van 'n veclvuldige tafelbediening}

Afgesien van aspekte wat reeds genoem is, word weer eens op die volgende sake die aandag gevestig (vgl. Van der Walt, 1990:189):

- Eerstens kan baie moeilik ontken word dat'n veelvuldige tafelbediening die motief van eenheid en gemeenskap aantans. 'n Bediening van vyf of ses groepe van die gemeente, terwyl die res van die gemeente toekyk, is nou eenmaal nie dieselfde as wanneer die hele gemeente gelyktydig aansit nie. Trouens, in hierdie verband sou myns insiens sterk gedink kon word aan 'n tersaaklike uitspraak soos 1 Kor. 11:33: "As julle saamkom om die nagmaal te vier, wag vir mekaar." Natuurlik moet hierdie teks binne die bepaalde Korintiese konteks van ryk en arm lidmate wat saam Nagmaal gevier het, gelees word, maar dit onderstreep myns insiens die motief van gemeenskap (koinonia) op besondere wyse. In vier, vyf, ses losstaande tafelbedienings kom daar weining van hierdie wag-vir-mekaar-motief na vore.

* Tweedens verleng die huidige praktyk die Nagmaalsviering onnodig. Nie dat ons moet huiwer om baie tyd aan die diens van die Here te bestee nie, maar die vraag gaan oor die sinvolle en liturgies verantwoorde besteding van 
tyd. Om 'n konkrete voorbeeld te gee: in 'n bepaalde grootstadgemeente in Pretoria, met 500 kommunikante en 'n kerkgebou met 'n groot liturgiese ruimte war 100 lidmate gelyktydig aan die tafel kan aansit, verloop die viering soos volg: elke tafelbediening duur sowat 10 minute; dus duur die totale viering 50 minute. Elke kommunikant sit dus vir 40 minute passief en toekyk hoedat ander Nagmaal vier. (In 'n studentegemeente van 2000 tot 3000 kommunikante sal die tydfaktor natuurlik nog 'n groter rol speel.) Hierdie reëling lyk nie vir my na 'n sinvolle manier van tydaanwending nie. Dit op sy beurt het tot gevolg dat weining gelowiges ontevrede is met 'n baie lae frekwensie van Nagmaalsviering per jaar (vier maal), terwyl Calvyn (en die Nuwe Testament: Hand 20:7) 'n weeklikse viering op die oog gehad het (Institusie, 4, 17:43/46)! Daarom is dit ook waardevol om aan die bord en beker 'n permanente plek voor die kansel saam met die doopvont te gee as voortdurende herinnering aan en tewens stille uitnodiging tot die maaltyd van die Here. Uiteraard moet dan alle bygeloof vermy word en mag die gedagte van 'n altaar nie weer posvat nie.

- Derdens skep die huidige praktyk wat genoem sou kon word 'n liturgiese leegte. Anders gesê, dit werk passiwiteit in die hand. Om vir langer as 'n halfuur 'n toeskouer te wees terwyl ander Nagmaal vier, is liturgies nie verantwoord nie. Selfs al sou die Skriflesing en liedere tydens die viering in berekening geword, kan dit nog nie die leegte vul en die passiwiteit deurbreek nie. By die instelling van die Nagmaal deur Christus was niemand 'n passiewe toeskouer nie.

- In die vierde plek trek die lang tydsduur van die Nagmaalsviering die verhouding tussen die verskillende liturgiese items skeef. Daar word minder gesing, korter gebid en selfs (volgens sinodale besluit!) korter gepreek. En dan vind daar ook nie tydens Nagmaalsondae katkisasie plaas nie. Al hierdie aspekte kan verander indien die tydsduur van die Nagmaalsviering ongeveer 15 minute duur, natuurlik sonder om enigsins skade te berokken en afbreuk te doen aan die wesenlike karakter van die Nagmaalsviering.

- 'n Vyfde gevolg van die huidige praktyk is dat ons 'n Nagmaalsviering sonder kinders kry. Al sou jong kinders nie aan die Nagmaal deelneem nie, beteken dit tog nie dat hulle nie Nagmaalsvierings behoort by te woon nie. Dit is eenvoudig ondenkbaar dat 'n gelowige kind vir die eerste keer met die Nagmaal kennis sal maak as hy/sy belydenis van geloof aflê. Die huidige lang vierings ontmoedig kinders om die Nagmaalsvierings by te woon. Ons bedoeling is natuurlik nie dat kinders sonder dat hulle bely- 
denis van geloof afgelê het, mag Nagmaal vier nie, maar as die belydenis vervroeg kan word na sê twaalf jaar (in Calvyn se tyd was dit tien jaar, maar dan opgevolg met 'n indringende na-belydeniskategese), plaas dit die kinders se teenwoordigheid by die Nagmaal in 'n nuwe konteks - maar dis 'n verhaal op sy eie (vgl. Van Wyk, 1989:93-94). Selfs by hulle wat nie (mag) Nagmaal vier nie, kan, by aanskoue van die brood en die wyn, die verlange opgewek word om aan die maaltyd deel te neem en so die begeerte na geloofsbelydenis aangevuur word.

\subsection{Die voordele verbonde aan 'n eenmalige tafel- en bankbediening}

- Eerstens kan gesê word dat 'n eenmalige, gesamentlike en gelyktydige Nagmaalbediening in die banke die eenheid van die gemeente op besondere wyse demonstreer (Bouwman, 1970:413; De Klerk, 1982:98). Dit is myns insiens ook nie korrek om selfs ten opsigte van die gebruik van bekertjies in die banke te sê dat dit slegs individualisme in die hand werk nie, want die feit dat die hele gemeente gelyktydig Nagmaal vier, dra onteenseglik by tot 'n eenheidsbelewing. Waar die vraagstuk van individualisme rondom die Nagmaalsviering in die Nuwe Testament na vore kom, gaan dit nie oor die hoeveelheid bekers nic, maar oor een groep (ryk) lidmate wat die gemeenskap met ander (arm) lidmate verbreek en hulle van die ander gedistansieer het (1 Kor. 11:20-22; Trimp, 1985:87). In hierdie verband wys Berkhof (1973:382) daarop dat die tafel en maaltyd "een uitermate kritische functie op politiek en sociaal terrein kunnen vervullen" en dat dit 'n "onthullende functie" kan uitoefen in die apartheidsproblematiek in SuidAfrika. Inderdaad kan dit 'n enorme effek op die samelewing uitoefen indien 'n swart hand die beker van vergewing en versoening uit 'n wit hand sou ontvang. (Soos bekend is die vigsvirus in geen omstandigheid deur die Nagmaalsbeker oordraagbaar nie (Jansen, 1990).) Tans kom die vraag na vore of daar inderdaad 'n wesentlike verskil is tussen die gebruik van 'n aantal groot bekers en 'n groot hoeveelheid klein bekertjies. In die genoemde voorbeeld van 'n Nagmaalsviering in 'n grootstadgemeente word by elke tafel ses bekers gebruik en as daar vyf tafels is, word in totaal dertig bekers gebruik. Dit bring ons voor die vraag waar die grens is tussen wat geoorloof en ongeoorloof is ten opsigte van die aantal bekers wat gebruik word. Die enigste werklike verskil hier kom daarin to uitdrukking dat in die geval van groot bekers dit na 'n medegelowige aangegee word wat as 'n uitdrukking van gemeenskap en versoening gesien kan word, terwyl dit by die afsonderlike klein bekertjies nie die geval is nie. 
* Tweedens duur die bankbediening veel korter, met al die voordele daaraan verbonde. Die Nagmaalsviering hoef dus nie die hele liturgie skeef te trek nie. Daar hoef nie korter gebid en gepreek of minder gesing te word nie, die kinders hoef nie 'n lang onbetrokke erediens mee te maak nie en die kategese hoef vir daardie Sondag nie afgelas te word nie. Die frekwensie van viering kan baie verhoog word, na ten minste een keer per maand (vgl. Van Wyk, 1970; Van der Merwe, 1974; Beukes, s.j.:27).

- 'n Derde voordeel is dat die instellingswoorde nie telkens herhaal hoef te word nie maar net een maal uitgespreek kan word en dat die sursum corda ("harte omhoog!") nie lankal vergete is as die laaste Nagmaalsganger die brood en die wyn ontvang nie.

Natuurlik moet hier bygevoeg word dat daar ook twee maniere van bankbediening moontlik is; enersyds 'n bediening met bekers wat vanaf die tafel geskied en daarvandaan na die hele gemeente uitgebrei word, sodat die maaltyd- en tafel- en bekermotiewe, en dus die simboliek van gemeenskap, versterk word, en andersyds 'n bediening slegs met bekertjies (en brood) in die banke.

\section{SAMEVATTING}

Indien bogenoemde gegewens kortliks saamgevat en op die belangrikste aspekte gekonsentreer word, kan op die volgende gewys word:

Indien 'n keuse gemaak moet word ten gunste van 'n Nagmaalsviering wat die naaste aan die oorspronklike instelling kom en die rykste aan simboliek is, moet sonder twyfel vir 'n tafelgemeenskap gekies word. Maar dan spreek dit vanself dat vir 'n maksimum realisering van die volle simboliek die héle gemeente gelyktydig moet aansit en maaltyd vier. 'n Verdeelde tafelgemeenskap illustreer nou eenmaal 'n gebroke eenheidsbelewing. Die ideaal is dus een tafel vir almal (Du Toit, 1977:282, met verwysing na Kuyper; W.J. De Klerk, 1964: 71).

Indien hierdie eerste keuse nie gerealiseer kan word nie, byvoorbeeld vanweë die duur koste verbonde aan 'n groot genoeg liturgiese ruimte, is ons tweede keuse 'n gelyktydige tafel- en bankgemeenskap waar die hele gemeente saam maaltyd vier. Vanaf die tafel word die viering dus na die banke uitgebrei deurdat die diakens/ouderlinge die brood en die bekers onder die kommunikante versprei. Soos Dijk (1952:220) sê: "de gehele kerk tot avondsmaaltafel in te richten zou het schoonste zijn". Die enigste beswaar in hierdie verband is dat dit die goeie toesig deur die ouderlinge mag benadeel. Hierdie probleem kan egter in 'n groot mate 
ondervang word indien die ouderlinge, saam met die diakens, by die uitdeling van die brood en wyn betrokke is. In elk geval ontvang die opsig en tug ook besondere aandag tydens huisbesoek en die ouderlingevergadering. Ten opsigte van (verwagte en onverwagte) besoekers, kan die toegang tot die Nagmaal deur middel van 'n afkondiging voor die erediens verduidelik word.

'n Derde keuse sou 'n roterende tafelgemeenskap kon wees soos tans in die GKSA gebruiklik is, veral wat klein gemeentes betref waar min tafels is. In groot gemeentes met baie tafels het hierdie metode meer nadele as voordele.

Die gebruik van individuele bekertjies in die banke sou 'n vierde plek kon inneem. Ons mag dit egter nié met die kenmerke van 'n valse kerk in verband bring nie. Om hier groot woorde soos liefdeloosheid, ongeloof en eiegeregtigheid te gebruik, is in die lig van ons bevinding nie verantwoord nie. Trouens, daar is wat metode betref 'n sekere parallellie tussen die doop- en Nagmaalspraktyk, tussen besprenkeling en onderdompeling enersyds, en kelkies en beker andersyds. Hoewel loegegee moet word dat die metode van onderdompeling die rykste simboliek bevat (vgl. Rom. 6:3-6) en ook in die bekende Doopformulier erken word en ons nêrens van die metode van besprenkeling in die Nuwe Testament lees nie, word besprenkeling tog deur gereformeerde kerke as verantwoorde doopmetode aanvaar. Insgelyks sou daar argumente aangevoer kon word waarom ook die praktyk van individuele bekerijies as Nagmaalmetode aanvaarbaar sou wees, al is dit waar dat die tafel-en bekergemeenskap ryker is aan simboliek.

Ten slotte. Dit is baie jammer dat daar rondom die Nagmaal wat by uitnemendheid 'n feestelike geleentheid behoort te wees, en 'n geleentheid van eenheid en gemeenskap met Christus en met mekaar, soveel stryd, onenigheid en somberheid ontstaan het. Dit is dringend noodsaaklik dat ons ook in hierdie geval die dinge waarop dit aankom sal onderskei (Rom. 2:18; Fil. 1:10) sodat ons huidige swaarwigtige en dikwels somber Nagmaalsgeleenthede verander kan word in 'n feesmaaltyd van herinnering, gemeenskap en belofte soos Christus dit inderdaad bedoel het.

\section{BRONNELYS}

BALKE, W. 1980. Het avondmaal bij Calvijn. (In Van't Spijker, W. et al. Bij brood en beker: Lecr en gebruik van het heilig avondmaal in het Nieuwc Testament en in de geschiedenis van de westerse kerk. Kampen : Dc Grool Goudriaan.)

BERKHOF, H. 1973. Christelijk Geloof : Een inleiding tot de geloofsleer. Nijkerk: Callenbach.

BERKOUWER, G.C. 1954. De sacramenten. Kampen : Kok. 
BEUKES, M. J. du P. s.j. Liturgiesc besinning ten opsigte van doop-en nagmaaleredienste. Henomde Tcologicse Studies, $33(1 / 2): 1.2)$.

BOUWMAN, H. 1970. Gereformeerd Kerkrecht: Het recht der kerken in de praclijk. Deel 2. Kampen : Kok.

BRIENEN, T. 1987. De liturgic bij Johannes Calvijn. Kampen : De Groot Goudriaan.

CALVIJN, J. Institutic of onderwijzing in de Christelijke godsdienst. Decl 3, bock 4. Delft: Naamloze Vennootschap W.D. Meinema. (Derde druk; vertaler A. Sizoo.)

COETZEE, J.C. 1990. Die instellingswoorde van die Nagmaal - 'n vergelykende studie van die vier berigte in die sinoptiese evangelies en 1 Korintiers 11. Koers, 55(1): 33-49.

DANKBAAR W.F. 1987. Communiegebruiken in de ceuw der Reformatic. Groningen : Rijksuniversitcit/IVL.

DE BRUYN, P.J. 1964. Bewaar jou gocie pand : Vraagstukke besien vanuil Gereformeerde standpunt. Potchefstroom : Pro Rege.

- DE KLERK, J.J. 1982. Liturgiese grondlyne. Pretoria : N G Kerk-Uitgewers.

DE KLERK, W.J. 1964. Wending? Vernuwingsgesprekke oor die Gereformeerde kerkpraktyk. Polchefsiroom : Pro Rege.

DIJK, K. 1952. De diens der kerk. Kampen : Kok.

DU TOIT, H.D.A. 1962. Dic stryd van dic drie Janne. Ned Geref Teologiese Tydskrif, 4(1): 47-54 Desember.

DU TOIT J.D. 1977. Tolius Versamelde Werke 3: Die erediens. Kaapstad : Tafelberg.

HANDELINGE, GKSA, Sinode Reddersburg, 1927

HANDELIN(iE, Algemene Sinode Geref Kerke in Suidelike Afrika, 1988

HANDELINGE, GKSA, Sinode Burgersdorp 1930.

HANDELINGE, GKSA, Sinode Potchefstroom 1988.

JANSEN, B.C. $1 \% 0$. Dic beker en sicktes: 'n Valstrik vir gelowiges in dic nagmaal. Die Kenkblad, 3(2x,40): 9-11. 4 April.

JANSEN, J. 1952. Korte verklaring van de Kerkorde der (iereformeerde Kerken. Kampen : Kok.

JONES, C. WAINWRI(;HT, (;. \& YARNOLD, E. (SJ). reds. 1983. The study of liturgy. London : SPCK.

KOEKEMOER, P.J.T. 1978. Bekers of kelkies by dic nagmaal? Die Henomer, 68(10): 11, 23. Januarie.

KOERS : BULLETIN VIR CHRISTELIKE WETENSKAP 1990. Spesiale vilgawe: artikels oor dic Nagmaal. Koers, 55(1).

KRUGER, J.C. 1980. Kerkvereniging in die lig van uilverkiesing en bekering. Pretoria : N G Kerkboekhandel.

KRUGER, L.S. 1956. Waarom is u lid van dic (iereformecrde Kerk? Preloria.

KUYPER, A. 1911. Onze ecredienst. Kampen : Kok.

LEKKERKERKER, A.F.N. 1\%1. De tafel des Heren. Bararn : Bosch \& Keuning.

MARTIN, R.P. 1982. The worship of God : Some theological, pastoral and practical reflections. (irand Rapids : Ecrdmans.

MuLLER, J. 1\%(x). Dic erediens as fecs. Preloria : N G Kerkheckhandel.

MüLL.ER, J.J. 1957. In U lig: Vrac beantwoord in dic lig van die Heilige Skrif (Decl I). Bloemfontein : Sucum.

NAUTA, D, 1971. Verklaring van de Kerkorde van de Gereformeerde Kerken in Nederland. Kampen : Kok.

NOORDMANS, O. 1986. Verzamelden werken. Decl IV : De kerk en hel leven. Kampen : Kok.

PASCH, H.Ph.J. 1930. Beker lecnoor kelkic : 'n Lesing. Burgersdorp : Alberl Times.

POLMAN, A.D.R. s.j. Onze Nederlandsche Geloolsbelijdenis : Verklaard uil het verleden geconfrontecrd met hel heden. Franeker: Wever.

RAYBURN, R.(j. 1989. O come, let us worship : Corporate worship in the evangelical church. Grand Rapids : Baker. 
RIDDERBOS, H. 1959. De komst van het koninkrijk : Jezus' prediking volgens de synoptische evangelicn. Kampen : Kok.

RUNIA, K. 1990. Maakt het uit hóé je avondmaal viert? Centraal Weekblad, 37(8):5, 25 Feb.

SPOELSTRA, B. 1989. Gereformeerde Kerkreg en Kerkregering: 'n Handboek by dic Kerkorde. Hammanskraal : HTS.

TRIMP, C. 1983. De gemeente en haar liturgie : Een leesbock voor kerkgangers. Kampen : Van den Berg.

TRIMP, C. 1985. Woord, water en wijn : gedachten over prediking, doop en avondmaal. Kampen : Kok.

VAN DELLEN, I. \& MONSMA, M. 1954. The Church Order commentary, being a brief explanation of the Church Order of the Christian Reformed Church. Grand Rapids : Zondervan.

VAN DER LINDE, G.P.L. 1983. Die Kerkorde : 'n Verklaring van die Gereformeerde Kerkorde. Potchefstroom : P T P.

VAN DER MERWE, D.C.S. 1974. Elkc Sondag nagmaal? Gewetensaak vir elke Christen. Polchelstroom : Pro Rige.

VAN'T SPIJKER, W, et al. 1980. Bij brood en beker : Leer en gebruik van hel heilig avondmaal in het Nieuwe Testament en in de geschiedenis van de westerse kerk. Kampen : De Groot Goudriaan.

VAN WYK, J.H. 1970. H(x dikwels mag ons nagmaal vicr? Die Kerkblod, 73(2051). 27 Mci.

VAN WYK, J.H. 1989. Brug tussen doop en nagmaal. In die Skriflig, 23(90):85-96. Junic.

VAN WYK, J.H. 1990. Die Woord is waardevol : 'n Dogmatiese besinning oor die reformatoriese Skrifbeskouing. Potchefstroom : PU vir CHO/DSP.

VRIJLANDT, MA. 1987. Lilurgiek. Delfi : Meinema.

VAN DER WALT, J.J. 1990. Dic rituaal van dic Nagmaal. Keers, 55(1):179-195. 